\title{
Activity of spore-crystal mixtures of new Bacillus thuringiensis strains against Dendrolimus pini (Lepidoptera: Lasiocampidae) and Spodoptera exigua (Lepidoptera: Noctuidae)
}

\author{
Edyta Konecka ${ }^{1} \bowtie$, Adam Kaznowski ${ }^{1}$, Matgorzata Stachowiak ${ }^{2}$, Mirosław Maciag $^{2}$ \\ ${ }^{1}$ Adam Mickiewicz University in Poznań, Faculty of Biology, Department of Microbiology, Umultowska 89, \\ 61-614 Poznań, Poland, phone: +48 61 8295935, fax: 061-829-5636, e-mail: edkon@amu.edu.pl \\ ${ }^{2}$ General Directorate of State Forest, Forest Protecting Unit Łopuchówko, Łopuchówko 1, 62-095 Murowana Goślina, \\ Poland
}

\begin{abstract}
We estimated the usefulness of spore-crystals preparations of the two B. thuringiensis isolates, MPU B9 and MPU B54, for reducing the number of pests. The potential insecticidal toxicities of $B$. thuringiensis isolates were assessed by the analysis of the genes coding for crystalline proteins. The activities of spore-crystals preparations were determined against Dendrolimus pini L. (Lepidoptera: Lasiocampidae) and compared with the toxicity of spores and crystals of B. thuringiensis subsp. kurstaki HD-1 from commercial biopesticide Foray. Although the analysis of crystalline toxin gene profiles indicated potentially higher activities of MPU B9 and MPU B54 crystals against the pests than that of HD-1, the toxicities of isolate and HD-1 preparations against $D$. pini caterpillars were similar. The $\mathrm{LC}_{50}$ amounted to $3.42 \times 10^{4}$ spores and crystals for HD-1, 3.36 $\times 10^{4}$ for MPU B9 and $3.5 \times 10^{4}$ for MPU B54. Additionally, the toxicity of the MPU B54 preparation was evaluated against Spodoptera exigua (Hubner) (Lepidoptera: Noctuidae). The $\mathrm{LC}_{50}$ was $4.5 \times 10^{5}$ spores and crystals of MPU B54, and $2.69 \times 10^{6}$ spores and crystals of HD-1. The $\mathrm{LC}_{50}$ of the MPU B54 preparation against $S$. exigua was approximately six-fold higher than that of HD-1. However, due to the very wide fiducidal limits for $\mathrm{LC}_{50}$ values, which for both preparations overlap to a large extent, the toxicity of the preparations should be considered the same. The varied profiles of crystalline toxin genes and important toxicity of spore-crystal mixtures of isolates against $S$. exigua and $D$. pini indicate the effectiveness of the mixtures against pests and make the strains an alternative for HD-1 for reducing the number of insects.
\end{abstract}

\section{KEY WORDS}

Bacillus thuringiensis, bacterial toxins, insecticidal toxicity, Lepidoptera, plant protection 


\section{INTRODUCTION}

Insect pests devastate approximately $18 \%$ of crops every year and contribute to a loss of $20 \%$ of stored food grains causing US\$ 100 billion damage per year all over the world. Lepidopteran caterpillars are considered as the most harmful pests (Nicholson 2007). Chemical insecticides are effective in reducing the pest number, but their usage contributes to the occurrence of resistance in insects. Furthermore, they have a wide spectrum of toxicity and act against non-target organisms, including natural enemies of pests. Preparations based on Bacillus thuringiensis are an attractive alternative due to the lack of harmful impact on human and other vertebrates, and low costs of production. There is still an urgent need to isolate a new, effective insecticidal factor that would be useful in plant protection and safe to nontarget organisms (Nicholson 2007).

One of the most important pests from Lepidoptera is Dendrolimus pini L. (Lasiocampidae) that damages the Scots pine Pinus sylvestris L. and causes severe economic losses. The insect's larvae eat a part or whole pine needles. They defoliate from spring to autumn (Davis et al. 2008). The pest larvae feed mainly on leaves (Albrecht and Davis 2012). Frequent and repeated defoliations caused by $D$. pini may result in tree death. The pest prefers Pinus sylvestris but feeds also on many other species of Pinus, Picea, Abies, Cedrus, Juniperus, Larix and Pseudotsuga (Davis et al. 2008). D. pini is a widely distributed pest of $P$. sylvestris in Central and Eastern Europe: in Germany (Le Mellec and Michalzik 2008), Poland (Sierpińska 1998), Lithuania (Gedminas and Žiogas 2008), Russia (Molet 2012), and Ukraine (Meshkova 2003; Hardin and Suazo 2012). There is also a growing concern about $D$. pini as a forest pest in Great Britain. The insect prefers sites with well-drained soil, warm summers, cold and dry winters. Due to climatic changes, the weather becomes warmer and drier, and as a result, the climate will be milder with colder winters. This suggests that future outbreaks of $D$. pini will be more serious and damaging in Great Britain, where there are only occasional, rare sightings of the insects (Ray et al. 2011).

Another lepidopteran pest is Spodoptera exigua (Hubner) (Lasiocampidae). It is a polyphagous insect that can develop in different vegetables, grasses, weeds and flowering plants in field and greenhouse throughout the world (Huffman et al. 1996; Capinera 1999). The pest is distributed in 101 countries of Africa, Asia, Europe, Australia, South and North America (Zheng et al. 2011). The insect larvae consume plants completely, leaving only roots and leaf veins. It is regarded as one of the most problematic agricultural pests worldwide that causes economic losses for the industry, because it can contribute to the reduction of crop production, especially commercial crops such as cotton and tobacco. The crop yields can be decreased not only by eating the whole plants by $S$. exigua larvae but also by leaving faeces in crops or causing significant scarring of fruit by the pest (Hua et al. 2013). The insecticide resistance of $S$. exigua is a serious problem in the management of this pest, probably because it attacks crops that are treated frequently with chemical pesticides (Capinera 1999).

The use of microbial insecticides is available in the market against lepidopteran pests. Preparations based on spore-crystal mixtures of $B$. thuringiensis comprise a large group of biological insecticides intended for plant protection against lepidopteran pests. B. thuringiensis crystals that are produced during sporulation include proteins toxic for insects. Various B. thuringiensis strains synthesize crystals that differ in protein compositions and thereby in the spectrum and amount of the crystal activity (Sarker and Mahbub 2012). The contents of crystalline inclusions and their potential toxicity can be estimated indirectly by the determination of the profiles of genes coding for the synthesis of crystal proteins (Nazarian et al. 2009). Despite formulations based on the bacterial spores and crystals available in the market against Lepidoptera, a growing concern prompted us to seek for new bacterial strains that could be applied in effective plant protection in both agriculture and forestry and be an alternative to both chemical pesticides and biological insecticides currently recommended for plant protection.

We attempted to find $B$. thuringiensis isolates that could be a valuable alternative to the HD-1 strain for reducing the number of lepidopteran pests in plants protection. We searched for isolates with diverse gene profiles of crystalline toxins and significant insecticidal toxicity of spore-crystal preparations against pests. We decided to determine the activity of spore-crystal preparation of a new B. thuringiensis isolate MPU B54 against $D$. pini and $S$. exigua and compare its toxicity 
with the activity of spore-crystal mixture of $B$. thuringiensis subsp. kurstaki HD-1 strain from Foray biopesticide that is recommended against insects of the order Lepidoptera. In order to predict the crystal toxicity of the isolate, identification of 39 groups and 22 subgroups of cry and cyt genes was conducted by using PCR assays. Additionally, we included B. thuringiensis MPU B9 isolate cultured from Cydia pomonella larva and determined the activity of its spore-crystal preparation against $D$. pini. Identification of cry genes of B. thuringiensis MPU B9 has been done previously (Konecka et al. 2007b) and the toxicity of its crystals for $S$. exigua has been determined (Konecka et al. 2012).

\section{MATERIAL AND MEtHOdS}

\section{Bacterial strains}

Three Bacillus thuringiensis strains were used in this study. B. thuringiensis MPU B54 was cultured from a soil sample collected in Wielkopolski National Park, Poland, $52^{\circ} 15^{\prime} \mathrm{N} 16^{\circ} 48^{\prime} \mathrm{E}$. It was identified by using API 50 CHB kit according to the manufacturer's instructions (bioMérieux, France). The presence of crystalline inclusions of MPU B54 strain was evaluated according to Smirnoff (1962). B. thuringiensis MPU B9 was isolated from the intestinal track of a dead C. pomonella larva (Konecka et al. 2007a). B. thuringiensis HD-1 was isolated from the commercial insecticide Foray (Valent BioSciences Corporation, Libertyville, USA).

\section{Insects}

D. pini larvae were collected from pine trees from their natural populations in central and western regions of Poland. As the analysis was a comparative study, the insects used in the experiments were in the same instar. The larvae collected from the natural populations were in the fourth instar and they were used in the experiment of determination of the activity of $B$. thuringiensis spores and crystals against insects on the following day after their delivery to the laboratory. All the larvae used were healthy, as was confirmed in the control sample in which 30 larvae were reared in the same conditions as those used in the experiment but with sterile distilled water applied instead of bacterial spore-crystal suspension on pine needles for insect feeding.
S. exigua larvae were from a standardized laboratory culture maintained in the Department of Microbiology, Adam Mickiewicz University, Poznań originated from insect culture of Institute of Plant Protection - National Research Institute, Poznań. The insects were reared in stable, standardized parameters of $26^{\circ} \mathrm{C}$ with $40-60 \%$ humidity and at 16:8 (day:night) period, with the use of a chamber simulating controlled cyclical environment conditions. The insects used in the experiments were seven-day-old when they reached the third instar.

\section{Identification of the genes of crystalline toxins of $B$. thuringiensis}

Identification of cry genes of B. thuringiensis MPU B9 has been done previously (Konecka et al. 2007). Thirty-nine groups and 22 subgroups of cry and cyt genes were analysed for $B$. thuringiensis MPU B54 isolate by using PCR method. The identification of the genes of MPU B9 and MPU B54 strains was conducted based on the same method. Amplifications were performed in a PCR mixture containing: $1 \mu \mathrm{g}$ bacterial DNA, $2.5 \mu \mathrm{l}$ of $10 \times$ PCR buffer (Novazym, Poland), $1 \mu \mathrm{l}$ of $5 \mathrm{mM}$ dNTPs (Novazym, Poland), 50 pmol of forward and reverse primers (Oligo.pl, Poland), $0.2 \mu 1$ of $5 \mathrm{U} / \mu 1 \mathrm{DNA}$ Allegro Taq polymerase (Novazym, Poland) and sterile distilled water to a total volume of $25 \mu \mathrm{l}$. PCR reactions were conducted in a MyCycler thermal cycler (BioRad, USA) according to the amplification conditions described by other authors. Genes cryl, cry 2 with their subgroups, as well as cry3, cry4, and cry7/8 were identified as proposed by Ben-Dov et al. (1997). Subgroups of cryl gene were detected according to Juárez-Pérez et al. (1997), Masson et al. (1997), and Monnerat et al. (2007). Bravo et al. (1998) and Jouzani et al. (2008a) have proposed amplification conditions for identification of cry5, cry 12 , cry 13 , cry 14 , and cry 21 genes. Detection of cry6, cry 15, cry16, cry18, cry20, cry22, cry25, cry26, cry $28, c y t 1$, and cyt2 genes was done according to Ejiofor and Johnson (2002). Identification of the cry9 gene and its subgroups was accomplished as described by Ben-Dov et al. (1999). Presence of cry10, cry17/27, cry24/40, cry29, and cry32 genes was evaluated as presented by Ibarra et al. (2003). Genes cryl9 and cry39 were identified according to Jouzani et al. (2008b). The condition for cryll and cryl3 gene amplification has been proposed by Bravo et al. (1998). Identifica- 
tion of $\operatorname{cry} 30 / 44$ genes was conducted as depicted by Ito et al. (2006). Detection of cry34 and cry35 genes was proposed by Schnepf et al. (2005). PCR products were mixed with $6 \times$ DNA loading dye (MBI Fermentas, USA) and electrophoresed in $1.5 \%$ Nova Mini agarose (Novazym, Poland). DNA was stained with ethidium bromide and electropherograms were documented by a BioPrint V.99 system (Vilber-Lourmat, France). Molecular weights of amplicons were estimated with GelCompar II 3.5 software (Applied Maths, Belgium).

\section{Preparation of B. thuringiensis spore-crystals mixtures}

B. thuringiensis MPU B9, MPU B54 and HD-1 strains were cultured on sporulation medium (Lecadet and Dedonder 1971) for five days at $30^{\circ} \mathrm{C}$. The spore-toxin mixtures of each strain were collected and weighted. Three mg of spores and crystals were suspended in 20 $\mathrm{ml}$ of sterile distilled water and their number in $1 \mathrm{ml}$ was calculated in a Bürker cell. Four dilutions of the mixture $\left(10^{-4}-10^{-7}\right.$ in $\left.10 \mu \mathrm{l}\right)$ were prepared.

\section{Activity of B. thuringiensis spores and crystals against $D$. pini}

Pinus sylvestris needles of equal length were immersed in the spore-toxin mixture for 5 minutes. One pine needle and one $D$. pini larvae of the fourth instar were placed in a separate Petri dish. For each dilution of the spore and crystals mixture, thirty larvae were used (three pseudoreplications with 10 insects each). Additional pine needles were supplemented to avoid insects' death from starvation - after eating the infected needle, the larvae were provided with other uninfected needles. As a negative control, thirty larvae were reared at the same conditions on needles without bacterial spores and crystals (the needles were dipped in sterile distilled water).

The number of spores and crystals on selected needles were determined for each crystal-spore dilution. The spores and crystals were rinsed from a needle and their number was determined in a Bürker cell under a light microscope. The pine needles dipped in spore-crystal suspensions of the lowest dilution had $7 \times 10^{6}$ spores and crystals on their surface. Each tenfold dilution of spore-crystal suspension resulted in tenfold lower number of spores and crystals on the surface of pine needles.

\section{Activity of B. thuringiensis spores and crystals against $S$. exigua}

The activity of B. thuringiensis MPU B9 crystal suspension against $S$. exigua has been published previously (Konecka et al. 2012). The toxicity of B. thuringiensis MPU B54 and HD-1 spores and crystals against $S$. exigua was determined in the same manner as described for MPU B9 (Konecka et al. 2012). Each dilution of spore-crystals suspension was spread on the surface of medium for insects rearing formed in rollers $3 \mathrm{~mm}$ high and $5 \mathrm{~mm}$ in diameter. The composition of the medium has been described by Poitout and Bues (1970). One $S$. exigua caterpillar was placed on each roller of the medium. Thirty larvae were used for each dilution (three pseudoreplications with 10 insects each). As a negative control, thirty larvae were reared in the same conditions on the medium in which sterile water was applied instead of bacterial spores and crystals.

\section{Calculation of LC50 B. thuringiensis spores and crystals against insects}

After a 14-day incubation for D. pini and seven days for $S$. exigua at $26^{\circ} \mathrm{C}$ with $40-60 \%$ humidity and at 16:8 (day:night) period, the number of dead insects was determined and the value of $50 \%$ lethal concentration $\left(\mathrm{LC}_{50}\right)$ was evaluated by probit analysis with BioStat 2009 Professional 5.8.4 software (AnalystSoft, Canada).

\section{Results}

B. thuringiensis MPU B54 harboured crylAa, crylAb, crylC, crylD, cryll, cry $2 A b, \operatorname{cry} 9 B$ and cry9E. We found cryl, cry2 and $c r y 9$ genes in both isolates. The strains differed in two genes only. The crylB gene was identified in MPU B9 but not in MPU B54, whereas the cryl Ab gene was detected only in MPU B54 strain.

The $\mathrm{LC}_{50}$ values of the $B$. thuringiensis preparations were calculated with consideration of the percent of mortality in control sample. All the control insects survived the experiments. The $\mathrm{LC}_{50}$ values of sporecrystal mixture of all $B$. thuringiensis strains against $D$. pini were similar and amounted to $3.42 \times 10^{4}$ spores and crystals of HD-1, $3.36 \times 10^{4}$ spores and crystals of MPU B9 and $3.5 \times 10^{4}$ spores and crystals of MPU B54 (Tab. 1). 
Table 1. $\mathrm{LC}_{50}$ of $B$. thuringiensis spore-crystal mixtures against D. pini

\begin{tabular}{|c|c|c|}
\hline Strain & $\begin{array}{c}\mathrm{LC}_{50} \text { of preparation } \\
\text { against } D \text {. pini* }\end{array}$ & $95 \%$ fiducidal limits \\
\hline HD-1 & $3.42 \times 10^{4}$ & $8.21 \times 10^{3}-8.56 \times 10^{4}$ \\
\hline MPU B9 & $3.36 \times 10^{4}$ & $2.66 \times 10^{3}-1.21 \times 10^{5}$ \\
\hline MPU B54 & $3.5 \times 10^{4}$ & $1.48 \times 10^{4}-6.78 \times 10^{4}$ \\
\hline
\end{tabular}

* The number of spores and crystals on the surface of pine needles per one larva.

The $\mathrm{LC}_{50}$ values against $S$. exigua were $4.5 \times 10^{5}$ spores and crystals of MPU B54, and $2.69 \times 10^{6}$ spores and crystals of HD-1 (Tab. 2). The $\mathrm{LC}_{50}$ of the MPU B54 preparation against $S$. exigua was approximately six-fold higher than that of HD-1 from Foray. However, due to the very wide fiducidal limits for $\mathrm{LC}_{50}$ values, which for both preparations overlap to a large extent, the toxicity of the preparations should be considered the same.

Table 2. $\mathrm{LC}_{50}$ of $B$. thuringiensis spore-crystal mixtures against $S$. exigua

\begin{tabular}{|l|c|c|}
\hline \multicolumn{1}{|c|}{ Strain } & $\begin{array}{c}\mathrm{LC}_{50} \text { of preparation } \\
\text { against S. exigua* }\end{array}$ & $95 \%$ fiducidal limits \\
\hline HD-1 & $2.69 \times 10^{6}$ & $1.28 \times 10^{6}-1.35 \times 10^{7}$ \\
\hline MPU B54 & $4.5 \times 10^{5}$ & $3.11 \times 10^{5}-7.13 \times 10^{6}$ \\
\hline
\end{tabular}

* The number of spores and crystals on the surface of medium per one larva.

\section{Discussion}

New $B$. thuringiensis strains synthesizing crystals with a wide variety of insecticidal toxins that show high activity against target insect pests are an issue of growing interest. In our research, we focused on searching for bacterial strains that harbour toxins active against the Lepidoptera pests and might be an alternative for B. thuringiensis strains used in the production of commercial biopesticides. In our paper, two isolates of different origins were investigated: B. thuringiensis MPU B9 was isolated from infected Cydia pomonella (Konecka et al. 2007a), whereas B. thuringiensis MPU B54 was recovered from a soil sample. For $B$. thuringiensis MPU B9, nine groups of crystalline protein genes and some of their subgroups have been identified previously (Konecka et al. 2007b) and additional subgroups of the detected genes and twenty one other crystalline toxins genes were determined. $B$. thuringiensis MPU B9 strain had crylAa, $1 B, 1 C, 1 D, 11,2 A b, 9 B$, and $9 E$ genes (Konecka et al. 2007b).

The profile of cry genes suggests the insect specificity of crystalline inclusions of $B$. thuringiensis. Cryl, Cry2, and Cry9 proteins, which genes were detected in MPU B9 and MPU B54, have been found to be toxic to pests from the order Lepidoptera (van Frankenhuyzen 2009). B. thuringiensis HD-1 from Foray carries crylAa, $1 A b, 1 A c, 2 A a, 2 A b$, and $2 A c$, but none of cry 9 genes and no other cryl besides crylA (Konecka et al. 2007b).

MPU B9 and MPU B54 strains seemed to have a higher activity of crystals against lepidopteran pests than B. thuringienis HD-1 from Foray because they had a higher number and variability of cry genes. Therefore, these two bacterial isolates were selected for the determination of the insecticidal activity of their sporecrystal preparations. The level of pesticidal toxicity of spores and crystals of MPU B9 and MPU B54 indicated the same effectiveness of the isolates' preparations against $D$. pini as that of HD-1 strain. The results may suggest that the Cry9 toxin, whose gene was found in the genomes of MPU B9 and MPU B54 but not in HD-1, is not active against $D$. pini.

The $\mathrm{LC}_{50}$ of the MPU B54 preparation against S. exigua was approximately six-fold higher than that of HD-1 from Foray. The reason of the high activity of MPU B54 spore-crystal preparation can be the contribution of Cry1C, Cry1D, Cry9B and Cry9E proteins in the crystals toxicity against the pest. The genes of these four insecticidal toxins were found in that isolate but not in HD-1 strain from Foray. The activity of CrylC against $S$. exigua has been confirmed by other researchers (Porcar et al. 2000; Lu et al. 2012; Ren et al. 2013). The toxicity of Cry1D has been reported as well (Porcar et al. 2000). Moreover, the toxins CrylC and CrylA, whose genes were found in MPU B54, can act synergistically against $S$. exigua (Xue et al. 2005) and this could also explain higher toxicity of sporecrystal preparations of the isolate than that of HD-1 against the insect.

The $\mathrm{LC}_{50}$ of crystals of B. thuringiensis MPU B9 exhibited high level of activity against $S$. exigua (Konecka et al. 2012). Moreover, the MPU B9 synthesizes spores and crystalline inclusions active also against $C$. 
pomonella (Konecka et al. 2007b), and crystals toxic for Leucoma salicis (Konecka et al. 2010; Konecka et al. 2011). The high value of the activity of spores and crystals of MPU B9 against $D$. pini determined in this study revealed the usefulness of the spore-crystal mixture of the isolate in plant protection.

In conclusion, the activity of spores and crystals of the two B. thuringiensis isolates studied exhibited important mortality levels against lepidopteran larvae. The diverse gene profiles of crystalline toxins and significant insecticidal toxicity of spore-crystal preparations of B. thuringiensis isolates against $S$. exigua and $D$. pini larvae make the strains a valuable alternative of HD-1 strain for reducing the number of lepidopteran pest.

\section{AcknOWLedgements}

This work was supported by the National Science Centre under Grant no. 2011/01/B/NZ9/00699 in 2011-2014.

\section{References}

Albrecht, E.M., Davis, E.E. 2012. Detailed survey tables. In: Pine Commodity-Based Survey Guidelines (ed.: R.C. Venette). Northern Research Station, USDA Forest Service, St. Paul, MN, USA, $19-31$.

Ben-Dov, E., Wang, Q., Zaritsky, A., Manasherob, R., Barak, Z., Schneider, B., Khamraev, A., Baizhanov, M., Glupov, V., Margalith, Y. 1999. Multiplex PCR screening to detect cry9 genes in Bacillus thuringiensis strains. Applied and Environmental Microbiology, 65, 3714-3716.

Ben-Dov, E., Zaritsky, A., Dahan, E., Barak, Z., Rosa, S., Manasherob, R., Khamraev, A., Troitskaya, E., Dubitsky, A., Berezina, N., Margalith, Y. 1997. Extended screening by PCR for seven crygroup genes from field-collected strains of Bacillus thuringiensis. Applied and Environmental Microbiology, 63, 4883-4890.

Bravo, A., Sarabia, S., Lopez, L., Ontiveros, H., Abarca, C., Ortiz, A., Ortiz, M., Lina, L., Villalobos, J., Peńa, G., Nuńez-Valdez, M.E., Soberón, M., Quintero, R. 1998. Characterization of cry genes in a Mexican Bacillus thuringiensis strain collection. Applied and Environmental Microbiology, 64, 4965-4972.

Capinera, J.L. 1999. Beet armyworm, Spodoptera exigua (Hübner) (Insecta: Lepidoptera: Noctuidae). Featured Creatures EENY- 105. Entomology and Nematology Department, Florida Cooperative Extension Service, Institute of Food and Agricultural Sciences, University of Florida, Gainesville, FL, USA. http://edis.ifas.ufl.edu/pdffiles/IN/IN26200. pdf (access on 17 August 2017).

Davis, E., Albrecht, E.M., Venette, R.C. 2008. Dendrolimus pini. In: Exotic pine pests: survey reference. Cooperative agriculture pest survey (ed.: R.C. Venette). Northern Research Station, USDA Forest Service, St. Paul, MN, USA, 122-130.

Ejiofor, A.O., Johnson, T. 2002. Physiological and molecular detection of crystalliferous Bacillus thuringiensis strains from habitats in the South Central United States. Journal of Industrial Microbiology and Biotechnology, 28, 284-290.

Gedminas, A., Žiogas, A. 2008. The influence of Dendrolimus pini $\mathrm{L}$. outbreak on the surrounding stands and forest litter entomofauna. Acta Biologica Universitatis Daugavpiliensis, 8, 287-296.

Hardin, J.A., Suazo, A. 2012. Control Procedures. In: New pest response guidelines. Dendrolimus pine moths (eds.: A. Hardin, J.A. Suazo). USDA Animal and Plant Health Inspection Service, US Department of Agriculture, USA, 107-122.

Hua, W., Zemerov, S., Wason, E. 2013. Spodoptera exigua, Animal Diversity. http://animaldiversity.org/ accounts/Spodoptera_exigua/ (access on 17 August 2017).

Huffman, R., Fuchs, T., Benedict, J., Parker, R., Sparks, S., Norman, J., Leser, J., Knutson, A., Minzenmayer, R., Frisbie, R. 1996. Management guidelines for the beet armyworm on cotton. Texas Agriculture Extension Service Bulletins.

Ibarra, J.E., del Rincón, M.C., Ordúz, S., Noriega, D., Benintende, G., Monnerat, R., Regis, L., de Oliveira, C.M.F., Lanz, H., Rodriguez, M.H., Sánchez, J., Peña, G., Bravo, A. 2003. Diversity of Bacillus thuringiensis strains from Latin America with insecticidal activity against different mosquito species. Applied and Environmental Microbiology, 69, 5269-5274. 
Ito, T., Ikeya, T., Sahara, K., Bando, H., Asano, S. 2006. Cloning and expression of two crystal protein genes, cry30Bal and cry44Aal, obtained from a highly mosquitocidal strain, Bacillus thuringiensis subsp. entomocidus INA288. Applied and Environmental Microbiology, 72, 5673-5676.

Jouzani, G.S., Abad, A.P., Seifinejad, A., Marzban, R., Kariman, K., Maleki, B. 2008. Distribution and diversity of Dipteran-specific cry and cyt genes in native Bacillus thuringiensis strains obtained from different ecosystems of Iran. Journal of Industrial Microbiology and Biotechnology, 35, 83-94.

Jouzani, G.S., Seifinejad, A., Saeedizadeh, A., Nazarian, A., Yousefloo, M., Soheilivand, S., Mousivand, M., Jahangiri, R., Yazdani, M., Amiri, R.M., Akbari, S. 2008. Molecular detection of nematicidal crystalliferous Bacillus thuringiensis strains of Iran and evaluation of their toxicity on free-living and plant-parasitic nematodes. Canadian Journal of Microbiology, 54, 812-822.

Juárez-Pérez, V.M., Ferrandis, M.D., Frutos, R. 1997. PCR-based approach for detection of novel Bacillus thuringiensis cry genes. Applied and Environmental Microbiology, 63, 2997-3002.

Konecka, E., Baranek, J., Kaznowski, A., Ziemnicka, J., Ziemnicki, K. 2012. Interaction between crystalline proteins of two Bacillus thuringiensis strains against Spodoptera exigua. Entomologia Experimentalis et Applicata, 143, 148-154.

Konecka, E., Baranek, J., Ziemnicka, J., Kaznowski, A. 2011. Activity of a mixture of Bacillus thuringiensis MPU B7 and MPU B9 protein crystals against white satin moth (Leucoma salicis L.) (in Polish with English summary). Postęy w Ochronie Roślin, 51, 393-396.

Konecka, E., Kaznowski, A., Ziemnicka, J., Ziemnicki, K. 2007. Molecular and phenotypic characterisation of Bacillus thuringiensis isolated during epizootics in Cydia pomonella L. Journal of Invertebrate Pathology, 94, 56-63.

Konecka, E., Kaznowski, A., Ziemnicka, J., Ziemnicki, K., Paetz, H. 2007. Analysis of cry gene profiles in Bacillus thuringiensis strains isolated during epizootics in Cydia pomonella L. Current Microbiology, 55, 217-222.

Konecka, E., Ziemnicka, J., Baranek, J., Kaznowski, A. 2010. Potential usefulness of Bacillus thuringiensis
MPU B9 protein crystals for reducing the number of white satin moth (Leucoma salicis L.) (in Polish with English summary). Postępy $w$ Ochronie Roślin, 50, 357-360.

Lecadet, M.M., Dedonder, R. 1971. Biogenesis of the crystalline inclusion of Bacillus thuringiensis during sporulation. European Journal of Biochemistry, 23, 282-294.

Le Mellec, A., Michalzik, B. 2008. Impact of a pine lappet (Dendrolimus pini) mass outbreak on $\mathrm{C}$ and $\mathrm{N}$ fluxes to the forest floor and soil microbial properties in a Scots pine forest in Germany. Canadian Journal of Forest Research, 38, 1829-1841.

Lu, Q., Zhang, Y., Cao, G., Zhang, L., Liang, G., Lu, Y., Wu, K., Gao, X., Guo, Y. 2012. A fragment of cadherin-like protein enhances Bacillus thuringiensis CrylB and CrylC toxicity to Spodoptera exigua (Lepidoptera: Noctuidae). Journal of Integrative Agriculture, 11, 628-638.

Masson, L., Erlandson, M., Puzstai-Carey, M., Brousseau, R., Juárez-Pérez, V., Frutos, R. 1998. A holistic approach for determining the entomopathogenic potential of Bacillus thuringiensis strains. Applied and Environmental Microbiology, 64, 4782-4788.

Meshkova, V. 2006. Foliage browsing insects risk assessment using forest inventory information. IUFRO Working Party 7.03.10 Proc. Workshop 2006, $100-108$.

Molet, T. 2012. CPHST Pest Datasheet for Dendrolimus pini. USDA-APHIS-PPQ-CPHST. http:/download. ceris.purdue.edu/file/3031 (Access on 17 August 2017).

Monnerat, R., Martins, E., Queiroz, P., Ordúz, S., Jaramillo, G., Benintende, G., Cozzi, J., Real, M.D., Martinez-Ramirez, A., Rausell, C., Cerón, J., Ibarra, J.E., Del Rincon-Castro, M.C., Espinoza, A.M., Meza-Basso, L., Cabrera, L., Sánchez, J., Soberon, M., Bravo, A. 2006. Genetic variability of Spodoptera frugiperda Smith (Lepidoptera: Noctuidae) populations from Latin America is associated with variations in susceptibility to Bacillus thuringiensis Cry toxins. Applied and Environmental Microbiology, 72, 7029-7035.

Nazarian, A., Jahangiri, R., Jouzani, G.S., Seifinejad, A., Soheilivand, S., Bagheri, O., Keshavarzi, M., Alamisaeid, K. 2009. Coleopteran-specific and putative novel $c r y$ genes in Iranian native $\mathrm{Ba}$ - 


\section{sciendo}

cillus thuringiensis collection. Journal of Invertebrate Pathology, 102, 101-109.

Nicholson, G.M. 2007. Fighting the global pest problem: Preface to the special Toxicon issue on insecticidal toxins and their potential for insect pest control. Toxicon, 49, 413-422.

Poitout, S., Bues, R. 1970. Élevage de plusieurs espèces de Lépodoptères Noctuidae sur milieu artificiel riche et sur milieu artificial simplifié. Annales de Zoologie Ecologie Animale, 1, 79-91.

Porcar, M., Martínez, C., Caballero, P. 2000. Host range and gene contents of Bacillus thuringiensis strains toxic towards Spodoptera exigua. Entomologia Experimentalis et Applicata, 97, 339-346.

Ray, D., Grieve, Y., Moore, R. 2011. Pine-tree lappet moth (Dendrolimus pini) future climate evaluation. http://www.forestry.gov.uk/pdf/FR_Aviemore_Update_2011_LappetMoth_\%28Ray\%29.pdf/\$file/ FR_Aviemore_Update_2011_LappetMoth_\%28 Ray\%29.pdf (access on 17 August 2017).

Ren, X.L., Chen, R.R., Zhang, Y, Ma, Y., Cui, J.J., Han, Z.J., Mu, L.L., Li, G. 2013. A Spodoptera exigua cadherin serves as a putative receptor for Bacillus thuringiensis CrylCa toxin and shows differential enhancement of CrylCa and Cryl Ac toxicity. Applied and Environmental Microbiology, 79, 5576-5583.

Sarker, N., Mahbub, K.R. 2012. Bacillus thuringiensis: an environment friendly microbial control agent. Microbiology Journal, 2, 36-51.
Schnepf, H.E., Lee, S., Dojillo, J., Burmeister, P., Fencil, K., Morera, L., Nygaard, L., Narva, K.E., Wolt, J.D. 2005. Characterization of Cry34/Cry35 binary insecticidal proteins from diverse Bacillus thuringiensis strain collections. Applied and Environmental Microbiology, 71, 1765-1774.

Sierpińska, A. 1998. Towards an integrated management of Dendrolimus pini L. In: Proceedings: population dynamics, impacts, and integrated management of forest defoliating insects (eds.: M.L. McManus, A.M. Liebhold). USDA Forest Service General Technical Report NE-247, USA, 129-142.

Smirnoff, W.A. 1962. A staining method for differentiating spores, crystals, and cells of Bacillus thuringiensis (Berliner). Journal of Insect Pathology, 4, 384-386.

van Frankenhuyzen, K. 2009. Insecticidal activity of Bacillus thuringiensis crystal proteins. Journal of Invertebrate Pathology, 101, 1-16.

Xue, J.L., Cai, Q.X., Zheng, D.S., Yuan, Z.M. 2005. The synergistic activity between Cryl Aa and Crylc from Bacillus thuringiensis against Spodoptera exigua and Helicoverpa armigera. Letters in Applied Microbiology, 40, 460-465.

Zheng, X.L., Cong, X.P., Wang, X.P., Lei, Ch.L. 2011. A review of geographic distribution, overwintering and migration in Spodoptera exigua Hübner (Lepidoptera: Noctuidae). Journal of the Entomological Research Society, 13, 39-48. 